\title{
Susceptibility of Selected Cotton Cultivars to Seedling Disease Pathogens and Benefits of Chemical Seed Treatments
}

\author{
Heping Wang, Graduate Research Assistant, and R. Michael Davis, Cooperative Extension Specialist, Department \\ of Plant Pathology, University of California, Davis 95616-8680
}

\section{ABSTRACT}

Wang, H., and Davis, R. M. 1997. Susceptibility of selected cotton cultivars to seedling disease pathogens and benefits of chemical seed treatments. Plant Dis. 81:1085-1088.

The susceptibility of 12 Upland cotton cultivars to three soilborne fungi, Pythium ultimum, Rhizoctonia solani, and Thielaviopsis basicola, was evaluated in greenhouse experiments. Based on symptom development and seedling survival, cultivars highly resistant to P. ultimum included Delta Pine (DP) 6166, Prema, DP 6100, and Maxxa. A relatively low incidence of pre-emergence damping-off caused by $R$. solani occurred in ChemBred 7, DP 6100, and Royale, although all cultivars subsequently suffered significant post-emergence damping-off. All cultivars were equally susceptible to T. basicola. In both greenhouse and field evaluations, there were no benefits of metalaxyl seed treatment in Pythium-resistant cultivars. Seed treatment with carboxinpentachloronitrobenzene for the control of Rhizoctonia-induced damping-off resulted in stand increases in all 12 cultivars in greenhouse tests and in 3 of 6 cultivars in field trials.

Seedling diseases cause the largest yield losses of any cotton disease in the United States. In 1995, the estimated nationwide reduction in cotton yields from seedling diseases was 828,199 bales (1). In California, seedling diseases caused an estimated loss of 81,994 bales in 1995, and similar lint losses have occurred in previous years (5).

The complex of pathogens associated with cotton seedling diseases, including Pythium spp., Rhizoctonia solani Kühn (teleomorph: Thanatephorus cucumeris (A. B. Frank) Donk), and Thielaviopsis basicola (Berk. \& Broome) Ferraris, confounds seedling disease control (6). Generally, appropriate fungicide seed treatments are the most effective control of seedling diseases (15). In California, virtually all cotton seeds are treated with at least 2 fungicides for protection from seedling diseases caused by Pythium spp. and $R$. solani (9). Recently, fungicides have been registered that reduce black root rot caused by $T$. basicola, and many acres are now planted with seeds treated with 3 or more fungicides.

Resistance is potentially the most economical method to manage seedling diseases because fungicide seed treatments could then be reduced or eliminated (7). Hefner (11) found that 1 of 10 cotton lines had both good emergence and good survival when challenged with $R$. solani. Gar-

Corresponding author: R. M. Davis

E-mail: rmdavis@ucdavis.edu

Accepted for publication 16 June 1997.

Publication no. D-1997-0730-01R

(C) 1997 The American Phytopathological Society ber et al. (8) evaluated the susceptibility of 7 cultivars to seedling disease and, although some cultivars were relatively tolerant to $P$. ultimum, none of the cultivars provided adequate stands without fungicide seed treatments.

Within the last several years, a number of new cotton cultivars have been introduced into California. The objective of this study was to evaluate the susceptibility of these new cultivars to infection by several soilborne pathogens, including Pythium ultimum, $R$. solani, and T. basicola. In addition, the benefits of individual fungicide seed treatments for the control of $P y$ thium- and Rhizoctonia-induced seedling diseases were evaluated in greenhouse and field tests.

\section{MATERIALS AND METHODS \\ Greenhouse evaluation of cultivar susceptibility to seedling diseases.} Twelve cultivars of Upland cotton (Gossypium hirsutum L.), including ChemBred (CB) 7, CB 305, Delta Pine (DP) 6100, DP 6166, Germain's Seeds (GC) 510, GC 610, GC 702, GC 717, Maxxa, Prema, Royale, and SJ-2, were evaluated for susceptibility to $P$. ultimum (isolate from soil from the Shafter Cotton Research Station in Kern County, California), $R$. solani AG-4 (isolate from a cotton seedling from the Kearney Agricultural Center in Tulare County, California), and T. basicola (original isolate from R. J. Wakeman, University of California [UC], Davis) under varied population densities in the greenhouse.

Inocula of $P$. ultimum and T. basicola were produced on potato-dextrose agar (PDA) plates, while inoculum of $R$. solani was produced on PDA plates amended with wheat bran (3 to 4 g/liter). Two-week- old plates of $P$. ultimum and $R$. solani were blended in water for 2 to $3 \mathrm{~min}$ in a Waring Commercial Blender (Dynamics Corporation of America, New Hartford, CT) at low speed, and mixed well with UC potting mix (1:1, peat:sand). Inoculum density of $P$. ultimum was determined by soil dilution plating onto a semiselective agar (14), while the inoculum density of $R$. solani was determined by placing soil plugs of known weight on a selective medium (13). Phialoconidia of $T$. basicola were counted with a hemacytometer under the microscope, suspended in water, and added to UC potting mix for the desired final concentrations.

Inoculum densities were adjusted to 30 and $150 \mathrm{CFU}$ of $P$. ultimum/g potting mix, 1,5 , and $9 \mathrm{CFU}$ of $R$. solani/100 g potting mix, and 75 and 150 conidia of $T$. basicola/g potting mix. The seed of all cultivars had germination rates of 95 to $100 \%$ when incubated 7 days at $18^{\circ} \mathrm{C}$, then 7 days at $25^{\circ} \mathrm{C}$. Seeds of all the cultivars were planted in a metal flat ( 50 by 35 by 8 $\mathrm{cm})$ as a replication to ensure all cultivars were under the same pathogen pressure. The cultivars were randomized in the flats, which in turn were randomized on a greenhouse bench. Ten seeds from each cultivar were planted $2 \mathrm{~cm}$ deep in a row in each flat. Flats were watered daily. Each trial consisted of four replications. Temperature in the greenhouse ranged from 10 to $20^{\circ} \mathrm{C}$. Pre-emergence damping-off and final stands were determined 3 to 4 weeks after planting in Pythium- and Rhizoctonia-infested soil. The susceptibility of 3 cultivars (Maxxa, Royale, and SJ - 2) to 3 isolates each of $P$. ultimum or $R$. solani was also evaluated in the greenhouse. All experiments were repeated once.

In evaluations of cotton susceptibility to black root rot caused by $T$. basicola, the incidence of black root rot (percentage of seedlings with black root rot symptoms) was recorded, and disease severity was measured according to the following scale: $0=$ no discoloration; $1=$ slight discoloration of hypocotyl or one small lesion; 2 = general discoloration of hypocotyl; $3=$ black discoloration of hypocotyl without loss of cortical tissue; and $4=$ constricted black hypocotyl with few or no healthy lateral roots and loss of cortical tissue.

Greenhouse evaluation of seed treatment benefits. The benefit of fungicide seed treatments against $P$. ultimum or $R$. solani AG-4 on the above 12 Upland cotton cultivars was evaluated. Seeds were 
Table 1. Susceptibility of selected cotton cultivars to seedling disease caused by Pythium ultimum or Rhizoctonia solani

\begin{tabular}{|c|c|c|c|c|}
\hline \multirow[b]{2}{*}{ Cultivar } & \multicolumn{2}{|c|}{ Pre-emergence damping-off $(\%)^{y}$} & \multicolumn{2}{|c|}{ Final stand $(10 \text { seeds })^{y}$} \\
\hline & P. ultimum & R. solani & P. ultimum & R. solani \\
\hline GC 717 & $100.0 \mathrm{a}^{\mathrm{z}}$ & $35.0 \mathrm{bc}$ & $0.0 \mathrm{c}$ & $5.3 \mathrm{ab}$ \\
\hline GC 510 & $95.0 \mathrm{a}$ & $41.7 \mathrm{ab}$ & $0.0 \mathrm{c}$ & $4.7 \mathrm{ab}$ \\
\hline GC 702 & $92.5 \mathrm{ab}$ & $38.3 \mathrm{abc}$ & $0.4 \mathrm{c}$ & $4.8 \mathrm{ab}$ \\
\hline GC 610 & $91.3 \mathrm{ab}$ & $29.2 \mathrm{bc}$ & $0.0 \mathrm{c}$ & $5.9 \mathrm{a}$ \\
\hline CB 305 & $82.5 \mathrm{ab}$ & $40.0 \mathrm{ab}$ & $1.3 \mathrm{c}$ & $4.3 \mathrm{abcd}$ \\
\hline Royale & $75.0 \mathrm{~b}$ & $25.0 \mathrm{c}$ & $1.0 \mathrm{c}$ & $5.4 \mathrm{ab}$ \\
\hline $\mathrm{CB} 7$ & $47.5 \mathrm{c}$ & $24.2 \mathrm{c}$ & $3.9 \mathrm{~b}$ & $4.5 \mathrm{ab}$ \\
\hline $\mathrm{SJ}-2$ & $41.3 \mathrm{c}$ & $43.3 \mathrm{ab}$ & $4.0 \mathrm{~b}$ & $2.7 \mathrm{~d}$ \\
\hline Maxxa & $18.8 \mathrm{~d}$ & $50.0 \mathrm{a}$ & $7.6 \mathrm{a}$ & $2.8 \mathrm{~cd}$ \\
\hline DP 6100 & $13.8 \mathrm{~d}$ & $24.2 \mathrm{c}$ & $8.3 \mathrm{a}$ & $5.7 \mathrm{a}$ \\
\hline Prema & $7.5 \mathrm{~d}$ & $37.5 \mathrm{abc}$ & $9.0 \mathrm{a}$ & $3.8 \mathrm{bcd}$ \\
\hline DP 6166 & $5.0 \mathrm{~d}$ & $32.5 \mathrm{bc}$ & $9.3 \mathrm{a}$ & $4.8 \mathrm{ab}$ \\
\hline \multicolumn{5}{|c|}{ Inoculum level } \\
\hline Low & $49.6 b^{z}$ & $21.7 \mathrm{~b}$ & $4.2 \mathrm{a}$ & $5.7 \mathrm{a}$ \\
\hline Medium & $62.1 \mathrm{a}$ & $26.5 \mathrm{~b}$ & $3.2 \mathrm{~b}$ & $5.5 \mathrm{a}$ \\
\hline High & & $57.1 \mathrm{a}$ & & $2.4 \mathrm{~b}$ \\
\hline
\end{tabular}

${ }^{y}$ Values are means of four replications in each of 2 inoculum levels of P. ultimum (30 and $150 \mathrm{CFU} / \mathrm{g}$ potting mix), or in each of 3 inoculum levels of $R$. solani (1, 5, and 9 CFU/100 g potting mix).

${ }^{\mathrm{z}}$ Means in a column followed by a common letter are not significantly different according to least significant difference at $P \leq 0.05$.

treated in a Hege Seed Treater (Hege Equipment Inc., Colwich, KS) with metalaxyl (Apron FL) at $0.31 \mathrm{~g}$ a.i./kg seed for the selective control of $P$. ultimum or with carboxin-pentachloronitrobenzene (PCNB; Vitavax-PCNB) at $0.92 \mathrm{~g}$ a.i. each $/ \mathrm{kg}$ of seed for the selective control of $R$. solani. Twenty treated and nontreated seeds were planted with three replications in flats filled with Pythium- or Rhizoctonia-infested potting mix at inoculum densities of $150 \mathrm{CFU} / \mathrm{g}$ or $9 \mathrm{CFU} / 100 \mathrm{~g}$, respectively. Pre-emergence damping-off and final stand data were collected 3 to 4 weeks after planting. The experiment was repeated once.

Field evaluation of seed treatment benefits. Three field experiments were conducted in 1995 and 1996 in the San Joaquin Valley, the primary cotton growing region in California. In 1995, field experiments were located at the West Side Field Station and the Kearney Agricultural Center. The same experiment was repeated at the Shafter Cotton Research Station in 1996. Selected cotton cultivars (GC 510, GC 710, Maxxa, Prema, Royale, and SJ-2) were planted at all field sites. The experiment included 4 seed treatments: (i) metalaxyl, $0.31 \mathrm{~g}$ a.i./ kg seed; (ii) carboxin-PCNB, $0.92 \mathrm{~g}$ a.i. each $/ \mathrm{kg}$ seed; (iii) metalaxyl + carboxin-PCNB, 0.31 g a.i./ $\mathrm{kg}+0.92 \mathrm{~g}$ a.i. each $/ \mathrm{kg}$ seed; and (iv) nontreated seeds. Treatments were arranged in a randomized complete block design and replicated four times. Each plot consisted of one 7.6-meter-long row planted with 120 seeds. Seedling stands in each plot were counted approximately 4 weeks after planting.

To measure the population densities of Pythium spp., R. solani, and T. basicola in experimental field sites, randomized soil samples (each consisting of 8 pooled subsamples in 1995 and 3 pooled subsamples in 1996) were collected at planting across each replication with a $2.54-\mathrm{cm}$-diameter soil sampler (0 to $20 \mathrm{~cm}$ deep). Soil population densities of Pythium spp. were determined by the soil dilution method described above, and species were identified according to van der Plaats-Niterink (16). Population densities of $R$. solani in the soil were obtained by a soil sieving method (17). Isolates of $R$. solani were further assigned to anastomosis groups using the cellophane method by pairing the isolates with "tester" strains (from E. E. Butler, UC Davis) and observing hyphal fusion $(3,4)$. A selective medium, T. basicola-carrotetridiazol-nystatin-pentachloronitrobenzene (TB-CENP) medium, was used to isolate and quantify T. basicola from the soil (12).

Data analysis. Data from the greenhouse tests and the field trials were analyzed by analysis of variance, least significant difference (LSD) mean separation, and homogeneity tests for combining trials with the Statistical Analysis System 6.04 (SAS Institute, Cary, NC).

\section{RESULTS}

Cultivar susceptibility. Since the relative performance of the cultivars was the same in each trial, the results of one experiment are presented (Table 1). There were no interactions between cultivar and trial, or between inoculum level and trial. Among the 12 Upland cultivars, DP 6166, Prema, DP 6100, and Maxxa were relatively resistant to Pythium-induced damping-off at the two inoculum levels, 30 and $150 \mathrm{CFU} / \mathrm{g}$ potting mix (the results of the two levels were combined since there were no interactions between cultivar performance and inoculation levels). Pre-emergence damping-off in these relatively resistant cultivars was less than $20 \%$. Final stand establishment was also greatest among these 4 cultivars. Cultivars GC 717,
702, 610, and 510, CB 305, and Royale were among the most susceptible cultivars to Pythium infection (the incidence of preemergence damping-off ranged from 71.3 to $100 \%$ ). Two cultivars, CB 7 and SJ-2, were considered to have intermediate levels of resistance to $P$. ultimum. Among all cultivars, the higher inoculum density of $P$. ultimum $(150 \mathrm{CFU} / \mathrm{g})$ caused $12.5 \%$ more pre-emergence damping-off than the lower inoculum density (30 CFU/g).

Maxxa was the most susceptible cultivar to $R$. solani; at least $50 \%$ of the seeds failed to emerge when the results from the 3 inoculum densities were combined (there were no interactions between cultivar performance and inoculum levels; Table 1). The cultivars DP 6100, CB 7, and Royale were among the most resistant cultivars to $R$. solani, although the differences in performance among the cultivars were generally small. Pre-emergence damping-off was positively correlated $(\mathrm{r}=0.772, P<$ $0.001)$ and the final stand was negatively correlated $(\mathrm{r}=-0.652, P<0.001)$ with increasing inoculum levels.

Virulence among the 3 isolates of $P . u l$ timum or $R$. solani varied, but the 3 cotton cultivars Maxxa, SJ-2, and Royale reacted similarly to all isolates. The incidence of Pythium-induced damping-off in Maxxa was $25 \%$ when the results of 3 isolates were combined, compared with $55.9 \%$ in SJ-2 and $82.5 \%$ in Royale. In Rhizoctoniainfested soil, the incidence of damping-off in Maxxa was $57.1 \%$ when the results of 3 isolates were combined, compared with $52.9 \%$ in SJ - 2 and $38.8 \%$ in Royale.

No significant differences in black root rot incidence or disease severity caused by T. basicola were found among the 12 cultivars. All cultivars were considered highly susceptible. Symptoms of black root rot were observed on 61 to $84 \%$ of the seedlings of all cultivars in the combined results from the 2 inoculum densities, while the disease severity index was 0.77 to 1.09 (data not presented). There were no significant interactions between cultivars and the 2 inoculum densities.

Benefits of fungicide seed treatment. The results of the two trials were combined since there were no significant interactions among treatment, trial, and cultivars. In Pythium-infested soil, the relatively susceptible cultivars benefited the most from the metalaxyl seed treatment (Table 2). For example, in GC 717, a relatively susceptible cultivar, the seed treatment decreased pre-emergence damping-off $87.5 \%$ and increased the final stand $86.0 \%$ relative to the controls. Among resistant cultivars, the benefits of the seed treatment were small, and the effect of the fungicide treatment on stand establishment was limited. In 4 cultivars (Prema, DP 6100, Maxxa, and SJ-2), there were no significant benefits of the metalaxyl seed treatment. In Rhizoctoniainfested soil, the carboxin-PCNB seed treatment significantly $(P \leq 0.05)$ reduced 
pre-emergence damping-off in all cultivars (Table 2). Stands of all cultivars were increased from 33.5 to $77.5 \%$ relative to the controls by the carboxin-PCNB treatment.

Field evaluation of fungicide seed treatments. The benefits of seed treatments in the field varied among seed treatments and cultivars (Table 3). The results from the 3 field sites were combined since there was no significant interaction between seed treatment and field site. The metalaxyl treatment did not significantly increase stands in 2 of the $P y$ thium-resistant cultivars, Maxxa and Prema. However, final stands of Royale, a cultivar highly susceptible to Pythium, were significantly improved by the metalaxyl seed treatment. Seed treatment with carboxin-PCNB alone increased stands of Maxxa, Royale, and GC 510. The combination of metalaxyl with carboxinPCNB did not generally improve the performance of carboxin-PCNB alone, although there was a beneficial effect in cultivar GC 702.

Populations of Pythium spp. were generally high (300 to 390 CFU/g dry soil) in all 3 field sites, and populations of $R$. solani were relatively low (1.5 to $2.8 \mathrm{CFU} / 100 \mathrm{~g}$ dry soil). T. basicola was not detected in any field site. $P$. ultimum represented 60 to $70 \%$ of Pythium isolates. P. irregulare and $P$. oligandrum were isolated occasionally.

\section{DISCUSSION}

The commercial cotton cultivars included in this study varied in response to the seedling disease pathogens. Different responses to seedling pathogens among cotton cultivars also were reported by Bush et al. (2), Garber et al. (8), and Hefner (11). Several cultivars in this study were relatively resistant to $P$. ultimum, but none were appreciably resistant to $R$. solani or T. basicola. Maxxa, the cotton cultivar currently grown on more hectares than any other in California, was resistant to $P$. ultimum, but was among the most susceptible cultivar to $R$. solani. Prema and 2 DP cultivars, 6100 and 6166, were also highly resistant to $P$. ultimum infection. Four GC cultivars (510, 610, 702, and 717), CB 305, and Royale were very susceptible to $P$. ultimum, while SJ-2 and CB 7 were considered to have an intermediate level of resistance to P. ultimum. Cotton cultivars responded similarly to various inoculum levels of $P$. ultimum or $R$. solani, and to the 3 isolates of P. ultimum or R. solani.

Black root rot is a disease of increasing importance in cotton disease management in California (12), even though T. basicola was not recovered from the 3 field sites in this study. All the cultivars included here responded similarly to $T$. basicola and were considered susceptible.

Table 2. Benefits of fungicide seed treatments for the specific control of Pythium- or Rhizoctoniainduced damping-off of Upland cotton ${ }^{\mathrm{x}}$

\begin{tabular}{lccccc}
\hline & \multicolumn{2}{c}{ Decrease in pre-emergence damping-off $(\%)^{\mathbf{y}}$} & & \multicolumn{2}{c}{ Increase in stands $(\%)^{\mathbf{y}}$} \\
\cline { 2 - 3 } Cultivar & P. ultimum & R. solani & & P. ultimum & R. solani \\
\hline GC 717 & $87.5^{z}$ & 46.6 & 86.0 & 33.5 \\
GC 510 & 26.7 & 39.2 & 30.0 & 34.0 \\
GC 702 & 80.8 & 40.0 & 86.5 & 40.0 \\
GC 610 & 84.2 & 46.6 & 76.5 & 45.5 \\
CB 305 & 35.8 & 47.5 & 39.5 & 39.0 \\
Royale & 41.6 & 52.5 & 51.0 & 62.5 \\
CB 7 & 43.3 & 75.0 & 50.0 & 73.0 \\
SJ - 2 & 5.0 & 55.0 & 14.0 & 59.0 \\
Maxxa & 5.8 & 72.5 & 12.5 & 73.5 \\
DP 6100 & 5.0 & 80.0 & 25.0 & 77.5 \\
Prema & 5.9 & 60.0 & 6.5 & 68.5 \\
DP 6166 & 9.2 & 66.7 & 22.5 & 59.0 \\
Least significant & & & & \\
difference, $P=0.05$ & 8.2 & 10.1 & 9.0 & 9.6 \\
\hline
\end{tabular}

${ }^{\mathrm{x}}$ Fungicide seed treatments were metalaxyl at $0.31 \mathrm{~g}$ a.i. $/ \mathrm{kg}$ seed for Pythium control and carboxinpentachloronitrobenzene at $0.92 \mathrm{~g}$ a.i. each $/ \mathrm{kg}$ seed for Rhizoctonia control. The inoculum densities of $P$. ultimum and $R$. solani were $150 \mathrm{CFU} / \mathrm{g}$ and $9 \mathrm{CFU} / 100 \mathrm{~g}$ potting mix, respectively.

${ }^{\mathrm{y}}$ Relative to pre-emergence damping-off or stands in nontreated control.

${ }^{\mathrm{z}}$ Values are means of two identical trials with three replications each; 20 seeds were planted in each treatment.

Seedling diseases are largely controlled by fungicide seed treatments. Each year, numerous fungicides are tested nationwide for efficacy in controlling seedling diseases. The performance of seed treatments are often dependent on the populations of soilborne pathogens (10). Likewise, the susceptibility of various cultivars also affects the benefits of seed treatments. Cultivars highly resistant to Pythium infection (Prema, DP 6100, DP 6166, and Maxxa) benefited little from the metalaxyl seed treatment in both greenhouse and field tests. Two cultivars (GC 510 and 702), highly susceptible to Pythium infection in greenhouse tests, also failed to benefit from metalaxyl in the field, possibly due to relatively lower inoculum pressure and increased microbial interactions in field soil than potting mix. In contrast, all cultivars benefited from the carboxin-PCNB seed treatment, consistent with their relatively high level of susceptibility to $R$. solani. Consequently, eliminating fungicides with specific activity against Pythium spp. may be feasible when using resistant cultivars, but there is no evidence that the use of fungicides with specific activity against $R$. solani or $T$. basicola could be altered in fields where these diseases occur.

\section{LITERATURE CITED}

1. Blasingame, D. 1996. Cotton disease loss estimate committee report. Page 227 in: Proc. Beltwide Cotton Prod. Res. Conf.

2. Bush, D. L., Bird, L. S., and Bourland, F. M. 1978. Variation in susceptibility to Rhizoctonia solani among MAR cotton cultivars. Page 21 in: Proc. Beltwide Cotton Prod. Res. Conf.

3. Carling, D. E., Leiner, R. H., and Kebler, K. M. 1987. Characterization of a new anastomosis group (AG-9) of Rhizoctonia solani. Phytopathology 77:1609-1612.

4. Castro, C., Davis, J. R., and Wiese, M. V. 1988. Quantitative estimation of Rhizoctonia solani AG-3 in soil. Phytopathology 78:12871292.

5. Davis, R. M., Nunez, J. J., Marshall, K. D., Munk, D. S., Vargas, R. N., Weir, W. L., and Wright, S. D. 1994. Chemical control of cotton seedling diseases in California. Pages 252-253 in: Proc. Beltwide Cotton Prod. Res. Conf.

6. DeVay, J. E., El-Zik, K. M., Bourland, F. M., Garber, R. H., Kappleman, A. M., Lyda, S. D., Minton, E. B., Roberts, P. A., and Wallace, T. P. 1989. Strategies and tactics for managing plant pathogens and nematodes. Pages 225266 in: Integrated Pest Management System and Cotton Production. R. E. Frisbie, K. M. El-Zik, and L. T. Wilson, eds. John Wiley \& sons, Inc., New York.

7. El-Zik, K. M. 1990. Integrated pest management and cotton pathology. Pages 15-19 in: Proc. Beltwide Cotton Prod. Res. Conf.

Table 3. Effects of fungicide seed treatment on cotton stand establishment in field trials, 1995-1996

\begin{tabular}{|c|c|c|c|c|c|c|}
\hline \multirow[b]{2}{*}{ Treatment } & \multicolumn{6}{|c|}{ Final stand (120 seeds/plot $)^{\mathrm{z}}$} \\
\hline & GC 510 & GC 702 & Royale & SJ-2 & Maxxa & Prema \\
\hline Nontreated & 77.7 & 79.8 & 65.9 & 79.7 & 74.8 & 92.8 \\
\hline Metalaxyl & 79.3 & 82.3 & 80.3 & 88.6 & 79.3 & 89.4 \\
\hline Carboxin-pentachloronitrobenzene & 84.7 & 86.0 & 88.0 & 88.7 & 85.3 & 97.3 \\
\hline Combination & 90.1 & 96.7 & 94.0 & 89.8 & 90.3 & 98.9 \\
\hline Least significant difference, $P=0.05$ & 6.6 & 9.7 & 6.2 & NS & 9.4 & 5.9 \\
\hline
\end{tabular}

z Values are means of three field trials with four replications each. NS = not significant. 
8. Garber, R. H., DeVay, J. E., Wakeman, R. J., and Vargas, R. 1991. The role of cultivar tolerance in cotton seedling disease control. Pages 163-165 in: Proc. Beltwide Cotton Prod. Res. Conf.

9. Garber, R. H., DeVay, J. E., Weinhold, A. R., and Matheron, D. 1979. Relationship of pathogen inoculum to cotton seedling disease control with fungicides. Plant Dis. Rep. 63 (3):246-250.

10. Garber, R. H., DeVay, J. E., Weinhold, A. R., and Wakeman, R. J. 1980. Pathogen inoculum a key factor in fungicide seed treatment efficiency. Page 19 in: Proc. Beltwide Cotton Prod. Res. Conf.
11. Hefner, J. J. 1968. Screening cotton for resistance to damping-off by Rhizoctonia solani. Pages 164-165 in: Proc. Beltwide Cotton Prod. Res. Conf.

12. Holtz, B. A., and Weinhold, A. R. 1994. Thielaviopsis basicola in San Joaquin valley soils and the relationship between inoculum density and disease severity of cotton seedlings. Plant Dis. 78 (10):986-990

13. Ko, W., and Hora, F. K. 1971. A selective medium for the quantitative determination of Rhizoctonia solani in the soil. Phytopathology 61:707-710.

14. Liddell, C. M., Davis, R. M., and Nunez., J. J. 1989. Association of Pythium spp. with carrot root dieback in the San Joaquin Valley of California. Plant Dis. 73:246-249.

15. Minton, E. B., Garber, R. H., Bird, L. S. DeVay, J. E., and Evrard, T. 1986. Effects of fungicide seed treatments that control specific pathogens on stand and yield of cotton. Page 20 in: Proc. Beltwide Cotton Prod. Res. Conf.

16. Plaats-Niterink, A. J. van der. 1981. Monograph of the genus Pythium. Studies in Mycology No. 21. Institute of Royal Netherlands Academy of Sciences and Letters.

17. Weinhold, A. R. 1977. Population of Rhizoctonia solani in agricultural soils determined by a screening procedure. Phytopathology 67:566-569. 